\title{
Spiritual Songs of Christian Pilgrimage to Jerusalem: An Intangible Feature of Coptic Ritual
}

\author{
Manal Mahmoud Abdelhamid \\ Associate Professor, Tour Guidance Dep., Faculty of Tourism and Hotels, \\ Alexandria University, Egypt.
}

\begin{tabular}{|c|c|}
\hline ARTICLE INFO & Abstract \\
\hline $\begin{array}{l}\text { Keywords: } \\
\text { Spiritual, Songs; } \\
\text { Pilgrimage; Coptic; } \\
\text { Jerusalem; Intangible; } \\
\text { Heritage. }\end{array}$ & $\begin{array}{l}\text { The pilgrimage represents an important feature in the religious } \\
\text { and social life of Copts in Egypt who used to make pilgrimage } \\
\text { to the local shrines scattered all over Egypt to show veneration } \\
\text { and glorification to God and saints. Beside these local visits, } \\
\text { Copts usually have an annual mystical pilgrimage to the } \\
\text { exceptional shrine of Jerusalem which occupies a } \\
\text { distinguished place in the heart of every Christian, as it is the } \\
\text { place that witnessed the different biblical events of the Christ's } \\
\text { life. One of the outstanding aspects of the Coptic pilgrimage to } \\
\text { Jerusalem is the folk songs which are usually recited by } \\
\text { women, describing all feelings and attitudes through the } \\
\text { different stages of the journey from the very beginning until } \\
\text { the end. They are composed of only two or three simple } \\
\text { rhyming verses with fixed literary and melodic molds and are } \\
\text { of unknown author or composer and have no written resource. } \\
\text { These folk songs are a real embodiment of the personal piety } \\
\text { of the Copts away from the political issues of the church. In } \\
\text { spite of the political situation with Israel that affected the } \\
\text { Coptic pilgrimage to Jerusalem, many Copts who are seeking } \\
\text { for salvation still make this unforgettable journey to participate } \\
\text { in the Easter rituals, offer sincere repentance for sins and } \\
\text { proudly get the prestigious title of "muqades" or "the holy } \\
\text { one". This study aims to show these songs as a crucial part of a } \\
\text { religious Coptic rite and also as an important intangible } \\
\text { cultural heritage that must be preserved and revitalized. }\end{array}$ \\
\hline
\end{tabular}

\section{Introduction}

According to The Oxford English Dictionary, "pilgrimage" is defined as "A journey (usually of considerable duration) to some sacred place as an act of religious devotion" (Dictionary, 1971), and it is originally derived from the Latin term peregri which means "Away from home" (Skeat, 1884).

Pilgrimage constitutes one of the most significant features of Coptic religious traditions. Copts ${ }^{1}$ are used to make pilgrimage to the holy shrines of saints and martyrs scattered all over Egypt during specific days in great parade called "mulid" 2, where they can 
make a vow, get blessing and benefit from the miraculous healing of holy water spring or holy oil exuded out of an icon (Viaud, 1991).

The pilgrimage tradition was already well established in ancient Egyptians' belief, as they used to make pilgrimage to Abydos, where the symbolic tomb of Osiris was located, to get blessing through erecting tombs with inscribed funerary stelae (Volokhine, 1998). The same attitude of cult transferred to Coptic era where the Christian saint or martyr replaced the Pharaonic deity (O. F. A. Meinardus, 2002).

The pilgrimage for the Copts, according to the Coptic Encyclopedia, is "a religious act of public worship of high spiritual and social value, consisting of an act of veneration offered directly to God and his saints, or to God through his saints. It is a complex event that implies, in effect, bodily fatigue, asceticism, and often a vow, with an offering being made and the poor receiving their share of alms. In short, pilgrimage is a religious act, perfect and complete, and if made with pure and righteous intent, it is a means of sanctification and glorification of God and his saints" (Viaud, 1991).

Beside the pilgrimage to more than sixty Coptic shrines inside Egypt, Copts used to make annual pilgrimage to Jerusalem ${ }^{3}$; the great ancient city that has a unique place in Christianity, as it witnessed the different stages of the life of the Christ which are mentioned in the bible; the crucifixion, the resurrection and finally his death and burying (Viaud, 1991).

Additionally, Jerusalem signifies a special case for the Copts, considering it as an integral extension of the holy landscape in which Egypt constituted a crucial part in the Flight of the Holy Family to Egypt ${ }^{4}$ (Gregorios, 1991). It is also the city to which the family of St. Mark the Apostle deported from Cyrene and in that blessed city, the Holy Spirit came upon the disciples in the house of Mary, the mother of Mark ( الاورشليمي, 2017).

According to the Coptic liturgy, Jerusalem is the symbol of eternity, always presents in the heart and mind of every Coptic person: "Those, O Lord, whose souls You have taken, repose them in the Paradise of joy, and in the region of the living forever, in the heavenly Jerusalem" (Danielson, 2000).

The entry into Jerusalem is one of the seven major feasts in the Coptic Church celebrated by the Copts under the name "Palm Sunday" which represents the beginning of the "Holy Week", the Copts commemorates the entry of the Christ into Jerusalem by carrying braided palm fronds decorated with flowers.

Certainly, Jerusalem is not an ordinary shrine, it is a unique place where the pilgrim can touch the monuments directly associated with the biblical events of the Christ's life and his disciples, as well as manifest the legends of the sacred book. There, faithful ones can attempt to surpass the barrier between the material and spiritual worlds and connect directly with the power of God by touching the Sepulcher of Christ or kneel at his birthplace in Bethlehem. Although, the pilgrimage is not obligatory "fard" in Coptic belief like Islam ${ }^{5}$, it is a great proud of any Coptic person to make the pilgrimage to Jerusalem, participate in the Easter rituals, glorify God, offer sincere repentance for sins, seek for salvation and above all get the prestigious title " muqades" or "the holy one" upon his return (Armanios, 2003; Bowman, 1992). 


\section{History of the Coptic Pilgrimage to Jerusalem}

Frenkel mentions that Jerusalem was a place of worship and pilgrimage to all three biblical religions, Jews, Christians, and Muslims, all of these communities used to make an annual pilgrimage to Jerusalem (Frenkel, 1996). Copts have literally visited Jerusalem since the days of the Bible: the Gospel of Luke mentions a foreign presence, that includes Egyptians (O. F. Meinardus, 2003).

In the early days of Christianity, pilgrimage to Jerusalem was rare; the Roman authorities did not encourage the travel to Jerusalem and it is noticeable that during the first two centuries, it was not easy to travel to Jerusalem which was only ruins after being destroyed by the Roman emperor Titus in 70 A.D (محمد, 2007).The Christians of the first centuries knew the cave in which the Christ was born in Bethlehem, they traveled individually to the Holy Land and to the Mount of Olives for praying and the acquisition of spiritual virtues (الاورشليمي, 2017).

However, according to Stephen Runciman, the great act of pilgrimage occurred after Empress Helena, the mother of the Byzantine Emperor Constantine the Great (306-337 A.D.), visited Jerusalem in 328 A.D., found the Holy Cross and identified the location of tomb of the Christ and the Golgotha ${ }^{6}$.Consequently, the Emperor ordered the building of the Church of the Holy Sepulcher there, and since that time, the pilgrimage to these places became a Christian tradition and great numbers of pilgrims immediately began to flow into this place (Runciman, 1951).

This great act of pilgrimage can be evident through some manuscripts; the first one is a letter from Paula to her friend Marcella in Rome, telling her that she made pilgrimage in 386 A.D., and the other one is a document called "Pilgrim Etheria" mentions the existence of Egyptian monks in Jerusalem (Aubrey, 1896; Bernard, 1891).

In 382 A.D., the Egyptian saint "Mary the Penitent" 7 went to Jerusalem and the Christians immortalized this saint by building a church after her name beside the church of the Holy Sepulcher. In year 384 A.D., four Coptic monks, known as " The Tall Brothers", went to Jerusalem, then an estimated number of fifty monks of Wadi Natrun dwelt around the Church of the Holy Sepulcher (Butcher, 1897).

The Copts are also mentioned as pilgrims to Jerusalem in the so-called "Letter of Guarantee" attributed to the Caliph Umar and dated A.H. 15 (A.D. 637). According to tradition, this covenant is said to have been made between the Caliph and the Greek Patriarch Sophronius: "And in order that the Georgians and Abyssinians depending on the Greek Nation be well established, let all other nations that go there on pilgrimage, Latins, Copts, Syrians, Armenians, Nestorians, Jacobites, and Maronites, submit to the patriarch Sophronius of Jerusalem" (O. F. A. Meinardus, 2002).

By the ninth century, Copts had firmly established a small community during the papacy of Patriarch Yaqub (810-830 A.D.) who constructed the church dedicated to Mary Magdalena which, until this day, is a refuge for the Orthodox and pilgrims (O. F. Meinardus, 1960).

The growth of the Coptic Orthodox presence in Jerusalem continued throughout the Middle Ages, Meinardus mentions that: "By the middle of the thirteenth century, a Coptic archbishopric of Jerusalem was well established to serve Coptic pilgrims to the 
Holy Land, among them Pope Gabriel III (1268-71). Beginning in the fourteen century, European pilgrims mentioned the Copts as one of the communities in the Church of the Resurrection. Coptic pilgrimage to the Holy Land continued throughout the Mamluk and Ottoman administrations. With the help of Archbishop Theophilus of Jerusalem (1935-45), a Coptic Orthodox Society for the Promotion of Pilgrimages to Jerusalem was established. Facilities for Egyptian pilgrims in and around Jerusalem were constructed to accommodate the increasing number of Coptic visitors" (O. F. Meinardus, 2003).

With the development of a pilgrimage infrastructure, Coptic Orthodox pilgrims also began the creation of specific ritualized practices as well; beside visiting the major Christian sites (like the Holy Sepulcher and Mount of Olives), they also developed exclusive traditions, sites, relics and miracles, for example, the invention of a relic of the Chains of Saint George by the Archbishop Abram (1820-54) (Wamboldt, 2013).

The Coptic Orthodox Church owns many properties in Jerusalem including Deir El Sultan, Deir Anba Antonius, Deir Mary Girgis and other chapels. The political struggle in the region has affected the Coptic presence in Jerusalem; during the Jordanian occupation of Jerusalem in the late 1950s and 1960s, diplomatic ties between Egypt and Jordan worsened, resulting in Deir El Sultan briefly became under the control of the Ethiopian Church, then in 1961, it was reverted to the Coptic control again (Basilios, 1991b).

The 1967 Six Day War with Israel changed the face of Coptic pilgrimage to Jerusalem, Israel gained control of the entire city and pledged to respect pre-existing religious control of sites. However, unlike the Egyptian government, the Ethiopian government had maintained friendly relations with Israel, resulting in growing pressure to change control of the monastery. On Easter eve of 1970, Israeli police forces occupied Deir ElSultan, changed the locks and handed it over to Ethiopian control. The Coptic claim upon this property in Jerusalem, as part of their heritage, is a frequent theme within the pilgrimage debate (Basilios, 1991a).

Consequently, Coptic Patriarch Shenouda III decreed a papal ban prohibiting Copts from making pilgrimage to Jerusalem and from performing this historical important ritual, on numerous occasions, he insisted that Copts would resume their pilgrimage only when Jerusalem was restored to Palestinian control (Wamboldt, 2013).

Despite the fact that most Copts are obedient to church decisions, some people feel distressed and sad to be prevented from visiting Jerusalem. Therefore, some Copts disagreed with these decisions and have gone to Jerusalem, but after admitting their mistakes, they published their apologies in the newspapers, and Pope Shenouda III forgave them.

Recently, there are a few exceptions allowed by His Holiness Pope Tawadros to visit Jerusalem including the aged Copts over sixty years as well as the Coptic families who have sons and daughters in the Diaspora (Wamboldt, 2013).

\section{The Spiritual Song as a Feature of the Coptic Pilgrimage to Jerusalem ${ }^{8}$}

In ancient times, the Coptic pilgrims used many routes to Jerusalem, the path followed by the Holy Family to Egypt, was the beginning of the appearance of the holy paths. 
After the arrival of the Blessed Virgin, Child Christ and Youssef Al Najar from Bethlehem via Sinai to Egypt and back again using the same route to Nazareth, Copts considered this path one of the holy paths that must be used by pilgrims to Jerusalem. This must have enhanced the spiritual experience, as travelers completed a journey that followed the ancient biblical plots, beginning with Christ's infancy in Egypt and ending with his death and resurrection in Jerusalem.

According to the Coptic tradition, the Holy Family followed this route to come to Egypt (Pl.1):

Bethlehem-Hebron-Gaza- Rafah- Al-Arish- Al-Falousiyat- Al-Farma- TanisSamanoud- Belqas (the Monastery of St. Damiana) - Damanhour- Wadi Al-NatrunGiza- Memphis- Albhanasa- Ashmounen- Jabal Qasqam.

The return route:

Jabal Qasqam - Wadi Qasqam - Albhanasa- Memphis Maadi- Old Cairo- al-MatareyahAin Shams- Atrib- Belbis-Bubastis-Samanud- Tanis- Al-Farma- Al-Arish- RafahJerusalem- Nazareth(بيشوي, 1999) .

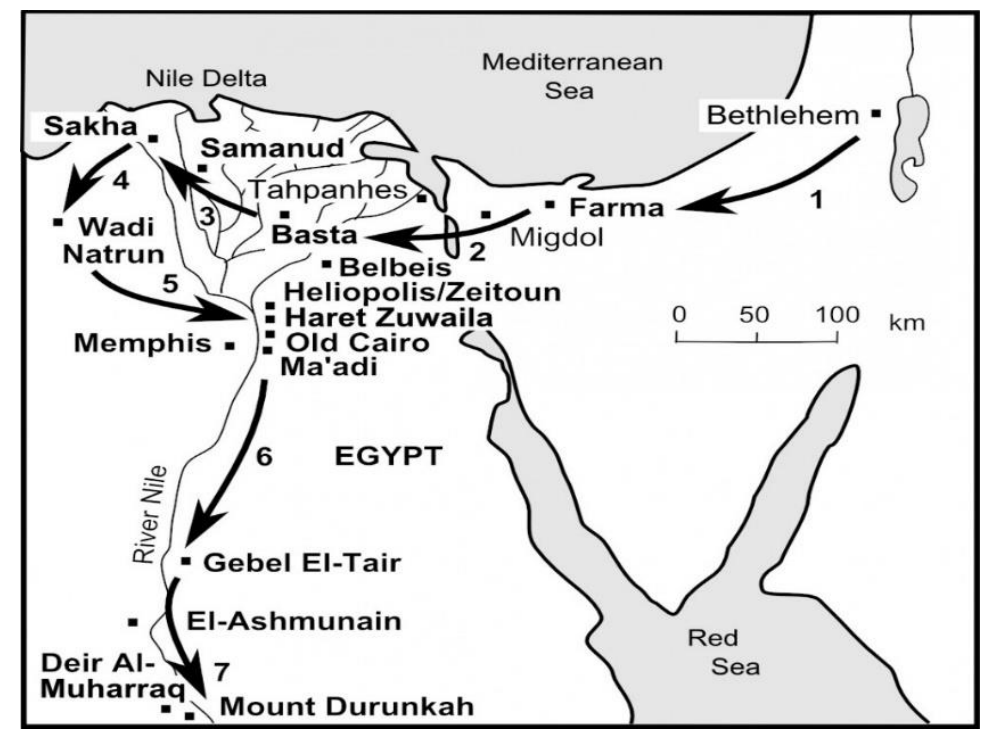

\section{Pl.1. Map shows the Route followed by the Holy Family to Egypt}

https://www.thebiblejourney.org/biblejourney 1/3-jesuss-childhood-journeysb/the-holy-family-flee-to-egypt/

Coptic pilgrims used to travel to Jerusalem by land or by sea: -

Land Road: started at Shagaret Mariam (Mary's Tree) in El-Mataria.(assembly point) and then went off to Belbis, then to Al-Arish, then Rafah to cross the boarders to Gaza, then to Hebron, to Bethlehem until they reached Jerusalem (El-Qods).

Sea Road: pilgrims would travel to Damietta where a ship would sail to Jaffa, then they would travel to Jerusalem (Alorshleme, 2012).

According to a manuscript of Ottoman Egypt, about 1704 A.D, which describes the pilgrimage journey of the Copts; the pilgrimage journey starts during the second week 
of Lent and ends after the celebration of the Easter, the pilgrims used to prepare some provisions and they travel together in a big caravan separated into two smaller convoys.

One of the outstanding features of the Coptic pilgrimage to Jerusalem is the songs that are a folk artistic mix of feelings and desires, composed in Egyptian dialect, describing in detail the whole journey from the very beginning until home return.

These spiritual songs are also called "Tahneen Songs" meaning the sad songs for the departure of the pilgrim, or "Sanctification Songs" referring to the holiness of the journey. Every song consists of two or three simple rhyming verses with repeated music template. All these songs are of unknown author or composer and have no written resource and usually recited by women depending on what they inherited from the ancestors.

These pilgrimage songs constitute a Coptic intangible heritage; according to UNESCO, the intangible cultural heritage $(\mathrm{ICH})$ can be defines as :"the practices, representations, oral traditions and expressions, knowledge, performing art, social practices, skills rituals and festive events as well as instruments, objects, artefacts and cultural spaces associated therewith that communities, groups and, in some cases, individuals recognize part of their cultural heritage", these aspects are inherited from the ancestors and passed on to the descendants, providing a sense of identity (UNESCO, 2003, 2005).

One can trace the different stages of this pilgrimage journey through these songs as follows (الفارس, 2007):

\section{1-Wishing to Make Pilgrimage to Jerusalem}

This visit is one of the important wishes of the Coptic Christian, or even the last wish in his old age; in the song, the Coptic person describes how he dreamed of the Christ, considering this dream as an indicator to fulfill his visit to Jerusalem:(معوض, 2018)

While sleeping, I dreamed of You, Christ

I woke up, decided to visit Jerusalem

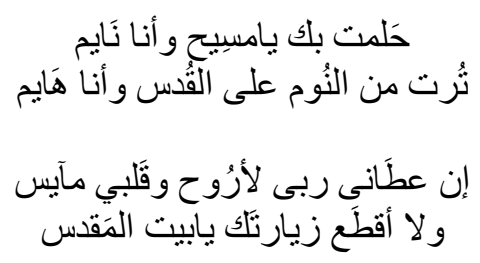

If God give me (money), I will visit

(Jerusalem) with joyful heart

I will never stop visiting you (Jerusalem)

Other song encourages people to travel to Jerusalem no matter the high cost, as God will financially compensate them (معوض, 2018):

Travel....Travel, do not hesitate

The Christ will make it easy for you

Spend all what you own on this journey, even if you become poor

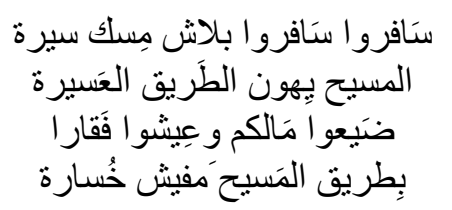

You will lose nothing as long as you are on the Christ's way 


\section{2-The Celebration of the Departure to Jerusalem}

After announcing the visit to Jerusalem, many songs are recited in the period before departure day and also on the departure day. During the days prior the departure to Jerusalem, the pilgrim expresses his happiness by hanging lights to decorate the house, distributing of coffee and making the vows as his wish of visiting Jerusalem became true, some of these vows are either in the form of great banquets for relatives and neighbors or providing the Church of Sepulcher with some curtains or furniture: ( ستانى, 2010)

With lamb meat and silver spoons I will sing, sing and furnish the Church of Sepulcher with decorated handkerchiefs I will sing, sing and furnish the Church of Sepulcher with embroidered handkerchiefs

I will sing, sing, and if God gave me (I will hang) lights and distribute coffee If God ordered, I will travel to Jerusalem

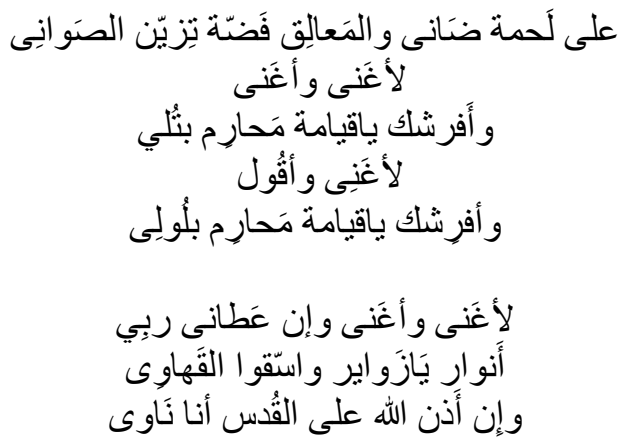

On the departure day, the song mentions the woman pilgrim entitled" muqadesa" wearing the most beautiful garments of the pilgrimage, and in another song, the man pilgrim or "muqades" follows the holy path where the Christ's dust will adorn him (معوض, 2018:

Where are you going "muqadesa" wearing the velour garment?

I am going to visit the Christ and help the poor one

Where are you going "muqadesa" wearing the gorgeous garment?

I am going to visit the Christ and return home

Your pilgrimage will adorn you" muqades" ...if you intend to go

Your pilgrimage will adorn you...the Christ's dust will adorn your forehead

Your pilgrimage will fit you..." muqades" if you intend to go

Your pilgrimage will fit you......the Christ's dust is on your foot

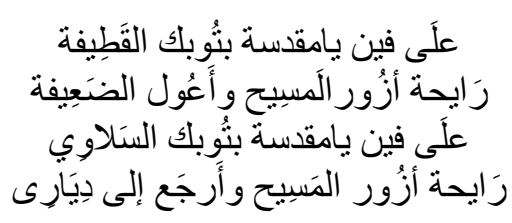

وقُسكك يِزينَك و أن نويت يامقدس وقُدسك بزينك

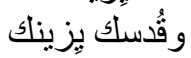

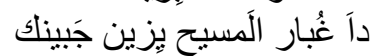

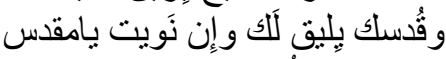

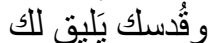

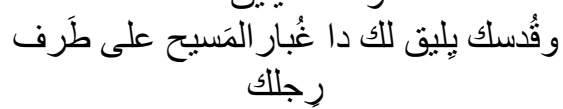

In this part of the farewell scene, the pilgrim asks his mother to pray for him to have a safe journey, to be accepted from the Christ and return home safely with the title of the “muqades": (معوض, 2018)

Oh my mother, on the upper floor, pray for me I pray for you, my son, my dear beloved one Oh my mother, pray for me to be "muqades" I pray for you my son in every church

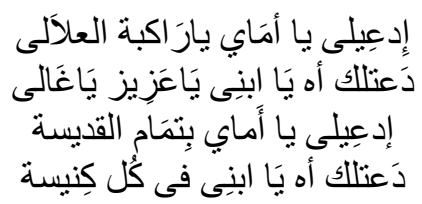


In spite of all difficulties facing the pilgrim through his journey to Jerusalem, the pilgrim announces his wishes to make the journey and see the Holy Light of the Christ before his death:

Oh God.....May I do not die and being buried Before seeing the holy light of the Christ and pay my debts

Oh God.......May I do not die and being carried to the tomb

Before seeing the Holy Light of the Christ and repent my sins

Oh God.....May I do not die and they wailed to me

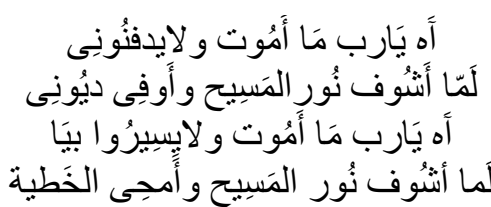

آه بارب مَا أمُوت و لاِِيكُو ا عَليا

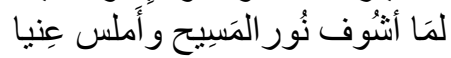

Before seeing the Light of the Christ and satisfy my eyes

\section{3- Describing the Route of the Journey}

In ancient times before using flights to visit Jerusalem, the pilgrims used to travel by land or sea after being gathered in a location on Red Sea called "Jenena" or "Makhada" to start the risky voyage. In the Coptic song, the captain of the ship reassures the pilgrims about his skills, so there is no need to be afraid, and after using plane and train, the songs were changed to mention these new transportations (ستاتى, 2010):

The beloved ones accompany me to "Jenena"

Please return home, I am so grateful

The beloved ones accompany me to "Makhada"

Please return home, I met the companions

\section{Oh Captain}

The waves are very high

Do not be afraid "muqadesa"

I am a skillful captain

Oh red train

Oh red train heading the Light of the Christ

Oh splendid train with four chimneys

Heading Jerusalem

I will sprinkle the plane with sweets

It is the plane carrying " muqades"

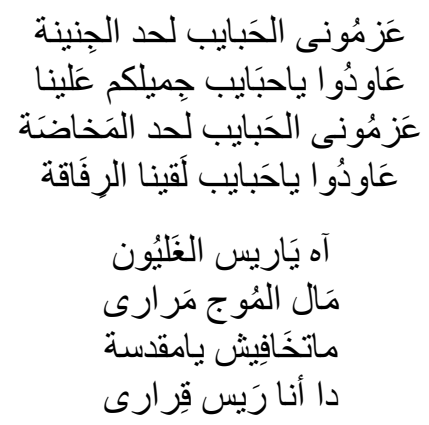

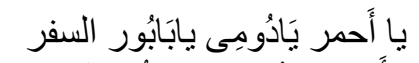

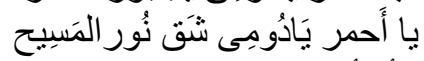

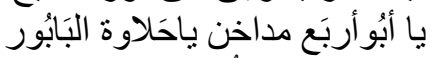
على القُس دَّ دَاخل

$$
\text { لا أَرشِكَ مِلبس ياطَيَارة باطَيارة }
$$

Sometimes the pilgrims needed a guide to show them the road to Jerusalem, usually this guide was either Levant or Jewish who knew the route very well (معوض, 2018):

Show me the way.... Jewish guide

Show me the way to the Christ

Show me the way.... Levant guide

Show me the way to the Christ

$$
\begin{aligned}
& \text { دِلنِي يَادَليل يا ابن الَيْهُوِِى }
\end{aligned}
$$

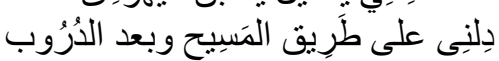

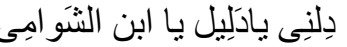

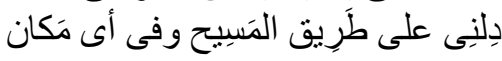


During the journey, the pilgrims also used to recite a song about the nativity of the Christ with the help of the midwife Salome who took care of the Virgin and the infant Christ, mentioning also the cave in Bethlehem where the Christ was born and visited by the three Magi (kings), this theme is also well represented in Coptic art (Pl.2): (ستانى, 2010)

The lonely Virgin Mary gave birth of the Christ

The lonely Virgin.......Her beloved son

Oh......angels of the sky...... Salome wraps the

$$
\text { infant Christ }
$$

He (the Christ) entered the Cave......was expelled by the Jews....He entered the Cave

He entered the Cave.....the kings (Magi) prostrated......the curtain closed

$$
\begin{aligned}
& \text { و لاحَشَ جِدَا ها وَلدُتُه العَدر ا مَريم } \\
& \text { و لاحَدش حِدَاهـا }
\end{aligned}
$$

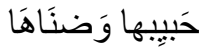

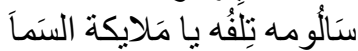

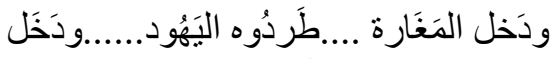

$$
\begin{aligned}
& \text { المَغارة }
\end{aligned}
$$

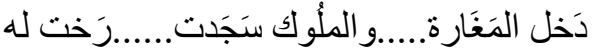

$$
\begin{aligned}
& \text { الِلسنَارة }
\end{aligned}
$$

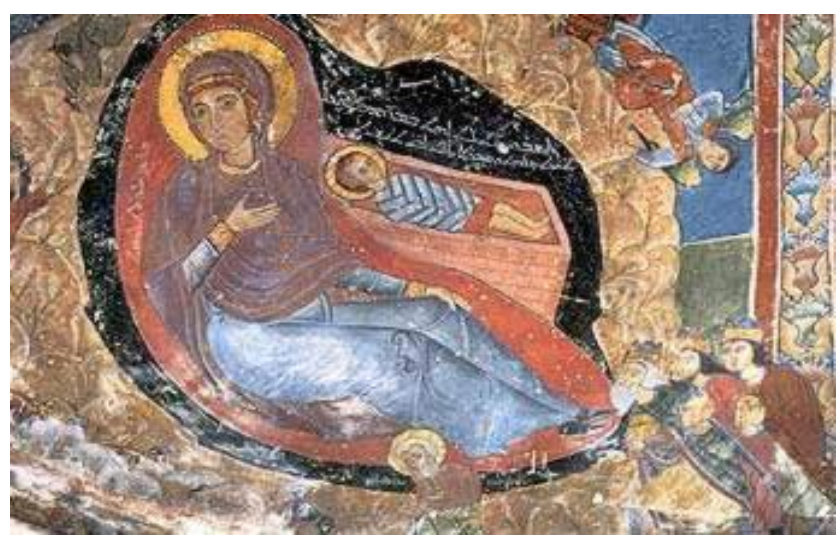

Pl.2. A Mural of the Nativity, the Church of the Holy Virgin in the Monastery of the Syrians at Wadi Natron, thirteenth century A.D.,(Ciggaar, Davids, \& Teule, 2003), F.7

The pilgrimage season starts with Lent where the Copts fast and refrain from meat and dairy, during the journey, the pilgrims used to eat only bread and salt symbolizing their grieving for the memory of the crucifixion of the Christ, these feelings and attitude are well illustrated in the pilgrimage song: (معوض, 2018)

In Lent, we ate only bread and salt

In the time of the Christ's crucifixion, we mourned sadly

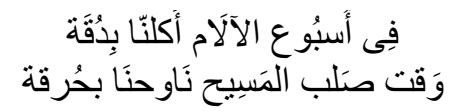

\section{4- Arrival to Jerusalem}

After a long journey, the pilgrim reaches the location of the great Church of the Holy Sepulcher that was built by Emperor Constantine the Great in 328 A.D., the tomb of the Christ and the cave where the Holy Cross was found are included in the complex. Near the Church of the Holy Sepulcher, the Copts have three chapels; the Church of the Four Incorporeal Beasts, the Church of the Angel and the Church of Saint George. Upon arrival, the Greek Orthodox Patriarch opens the doors of the Church of the Holy Sepulcher for pilgrims who proceed around the interior of the church until they reach the Coptic chapel near the tomb of the Christ where they pray mass, then everyone takes blessing at Christ's Sepulcher (Armanios, 2003). 
The Copts consider the Coptic chapel in the Church of the Resurrection, which is dedicated to the Holy Virgin, the holiest of all the sacred sites, for the Coptic altar is believed to be erected against the place where Christ's head rested at the time of his burial (O. F. A. Meinardus, 2002).

This splendid scene is comprehensively described in the songs recited by pilgrims upon arrival representing their joy and gratitude (الفارس, 2007):

Brick over brick..... Who built you Sepulcher Church?

Brick over brick

A miraculous building

(They) laid the foundation, I (the Church) was built

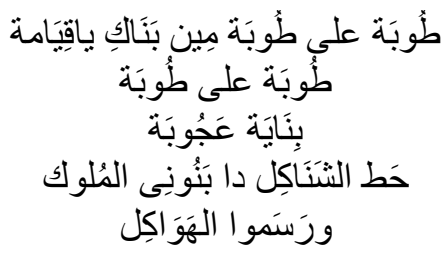

by kings...They (kings) built the sanctuaries

Sepulcher Church has stone threshold Stone threshold

Sepulcher Church has ruby threshold Ruby threshold

Oh Holy Cross.... the Tomb of the Christ is in You (Sepulcher Church)

What did you see "muqades"?

On the door (of the Church of Sepulcher) upon entry?

I saw the Greek Patriarch

Praying holding censers

عَبْها حِجَارة كِنيستأك ياقِيامة

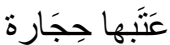

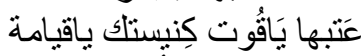
عَتبها يَاقِّوت

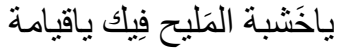

قَبر المَسيِح فَّح

إيش رَأيت بَامقدس

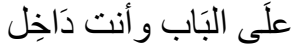

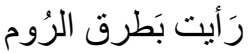

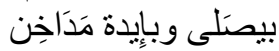

What did you see "muqades"?

While you are at "Mangalia" (Gospel stand)

I saw the Greek Patriarch

Prays and wears the tunic

$$
\begin{aligned}
& \text { إِيش رَأيت يَامقدس } \\
& \text { وَ إنتا علَّى المَنجَلِية } \\
& \text { رَأيت بَطرق الرُوم الَّاتِ } \\
& \text { بيصَلى و لآبس الثُونية }
\end{aligned}
$$

For the remainder of the Lent period, the pilgrims visit the other holy locations all over Jerusalem, including Ain Silwan where they drink the holy water, then they proceed to Bir Yaqub ( Jacob's Well) ${ }^{9}$ and climb Jabal Al Soud (The Mount of the Ascension) where the footprints of the Christ are imprinted on a rock. Later, they visit the tomb of the Virgin Mary in Gethsemane where they pray mass on the spot, some of these places are mentioned in the pilgrimage song (معوض, 2018):

Heading Jacob's Well....."muqades"

Heading Jacob's Well

You would like to visit and make pilgrimage

Heading Samriya's Well...."muqades"

It is a prosperous visit

Heading Canaan Land ${ }^{10}$......"muqades"

Heading Canaan Land

You would like to visit and make pilgrimage

It is an annual visit

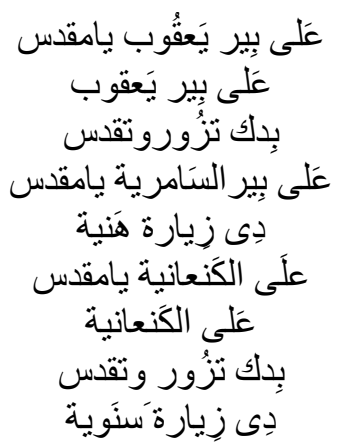


In the following week, the pilgrims celebrate the ceremonies of "Palm Sunday"11 inside the Church of the Holy Sepulcher, then going out in a great procession holding palm leaves following the same route used by the Christ. Coptic pilgrims also go to the Jordan River (Bahr Al Shareaa) to get the blessing of the water in which the Christ was baptized, they wear white clothes adorned with the cross and Christian themes then immerse themselves in its water, hence using these holy clothes to be shrouded with after death (Pl.3).

If you intended "muqades" to visit Jerusalem, take a white garment

At Bahr Shareaa enjoy washing it (immerse yourself)
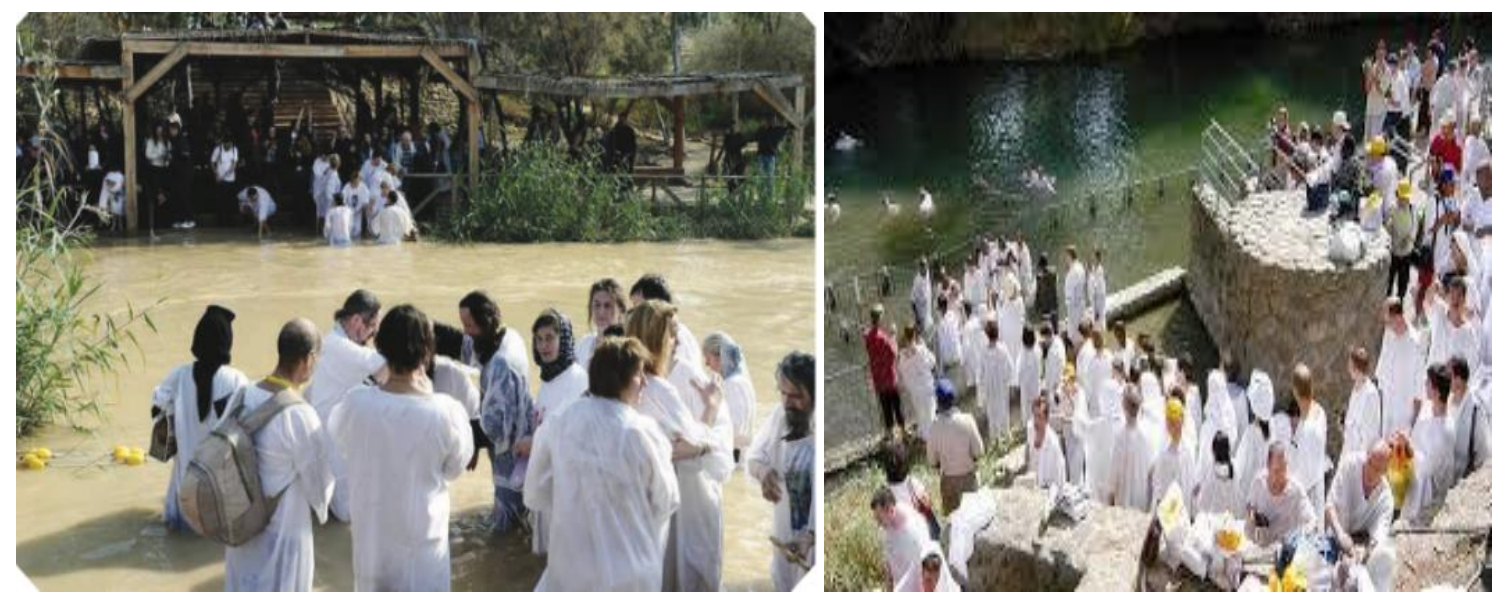

Pl.3. The Coptic Pilgrims wearing white clothes and immerse themselves in Jordan River

https://www.folkculturebh.org/ar/issue=41\&page=showarticle\&id

During that week, they also pray traditional services in their own chapels, until the Church of the Holy Sepulcher is reopened for communal prayer on Good Friday.

By Saturday, which is known as the Saturday of Light or "Sabt Al Nour", preparations are being made for the most miraculous occasion associated with the Easter services in Jerusalem; the "Miracle of the Holy Fire", which comes out of the Christ's tomb, and is used to light candles that have been pre-purchased by pilgrims for this great event (Pl.4). The Holy Light does not burn any person touches it and appears as a bright pillar, from which the candles and lamps are lit. This holy light flies like a pigeon throughout the church to light all the surrounding churches (Alorshleme, 2012). 


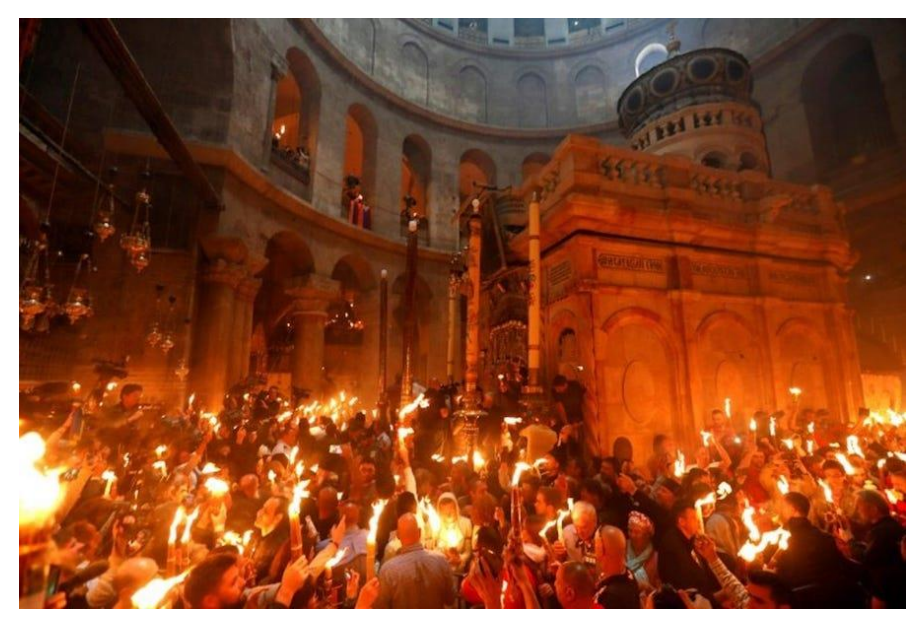

Pl.4. The Miracle of the Holy Fire and the Pilgrims holding Candles https://www.businessinsider.com/afp-christians-mark-easter-at-jerusalem-site-of-jesussresurrection-2017-4

Definitely, this is the climax of the entire journey and the pilgrims would keep those candles, which were lit by the Holy Fire, as souvenirs to give to friends and family upon return home. On the first Saturday after Easter, the doors of the Church of the Holy Sepulcher are reopened and pilgrims enter to pray, most of them enter the tomb of the Christ to take the final blessing, then they depart to Egypt.

This marvelous experience of the pilgrimage is even recorded upon the pilgrim's body with a specialized tattoo that serves both as commemorative souvenir as well as an apotropaic symbol (O. F. A. Meinardus, 2002).

As in Coptic houses, where saintly depictions in the form of amulets or small icons are extensively displayed, these tattoos are, along with candles, rosaries and pictures are the keepsakes taken home from Jerusalem to commemorate this historical even and also considered to be a sort of "baraka" or blessing (Carswell, 1958).

In his book Coptic tattoo designs, John Carswell mentions this tradition of tattooing among Copts who visit Jerusalem, the most prevalent tattoos are the cross (Jerusalem Cross), the resurrection of the Christ from the glorified tomb with the word Jerusalem, the pilgrim's name and the date of his visit beneath, besides the figures of the Virgin, favorite saints or martyrs and some pilgrims choose to tattoo only the year of the pilgrimage to memorialize it for posterity (Carswell, 1958) (Pl.5). That tradition is mentioned in the pilgrimage song (ستانى, 2010; معوض, 2018):-

Call me with your voice Christ, Call me

I wish to visit the Copt's Monastery

Straighten my right arm to get Cross tattoo

I wish to visit the Christ's Monastery

Straighten my right arm to get date tattoo (the visit date)

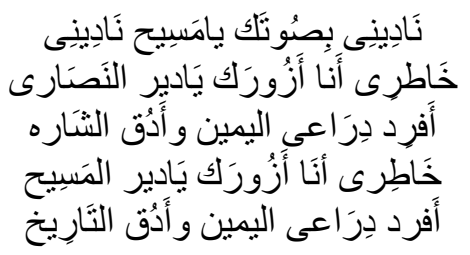



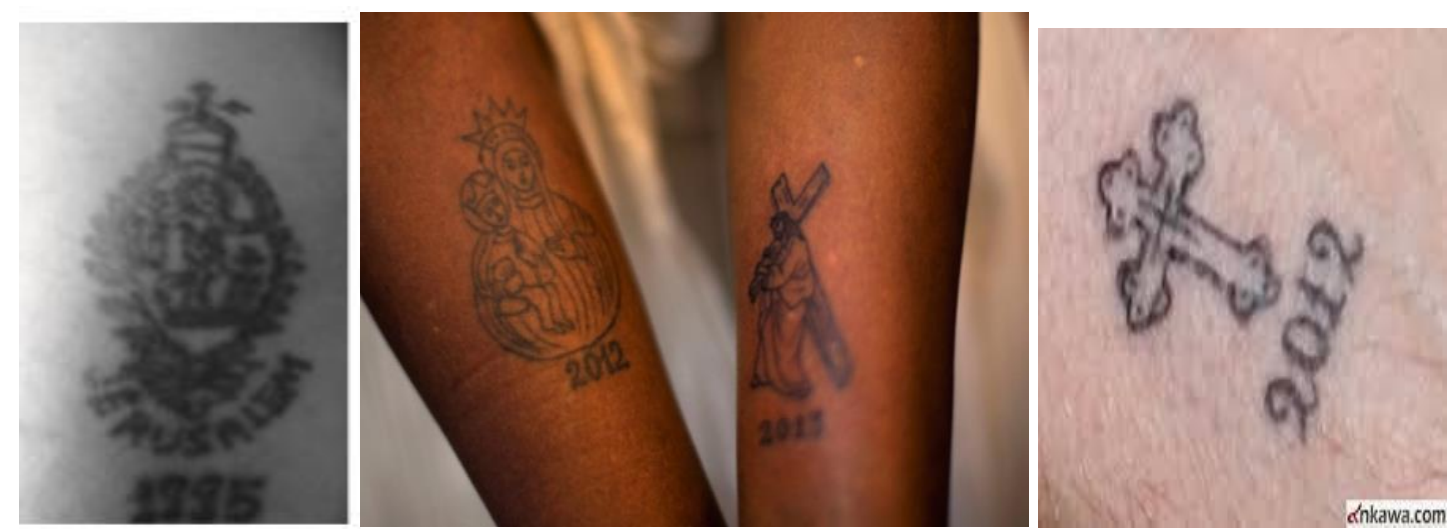

Pl.5. Different Forms of Tattoos

https://newspaper.annahar.com/article/52363; أملاك الكرسى الأورشليمى والشرق الأدنى للأقباط الأرثوذكس

The Coptic family of Yaqoub Razouk does tattoos for pilgrims, they came from Egypt to Jerusalem in the eighteenth century, most of his customers are Coptic beside Armenians, Syrians, Latins and the Sicilians.

Yaqoub has tattooed patterns engraved on olive wooden panels, these shapes are transmitted to the hands of the pilgrim manually by needles, but recently, he has got an electronic needle that can do colorful tattoos with less pain (الاورشليمي, 2017).

\section{Discussion and Conclusion}

Through the pilgrimage songs, the Coptic folk artist was able to draw a detailed painting of the Christian pilgrimage to Jerusalem, starting from the mere wish of visiting the Christ until the beating of tattoos that commemorates this dear visit to the heart of every Coptic person.

By reading these songs, a person can imagine the entire journey since the pilgrim is leaving his house wearing the most luxurious and beautiful clothes after saying goodbye to the family and relatives, the means of transportation available at that time, passing by the description of the route of the trip and the feelings experienced by the pilgrim, along with the food that is consumed and the moment of arrival, the first look at the Church of the Sepulcher, showing all the other holy sights of the trip, and ending with the tattooing to commemorate this unforgettable memory.

These folk songs, either the songs of the pilgrimage to Jerusalem or those other ones recited by the Copts while visiting the holy shrines in Egypt, have some common characteristics:

- They are composed of only two or three simple rhyming verses.

- They have two molds, a fixed literary mold and a melodic mold which are inherited from ancient times.

- They can be considered religious songs, as they contain a detailed description of one of the Coptic religious rite which has become an integral part of Copts' religious faith. 
- They play an important role in preserving an aspect of the Coptic folklore, helping to pass it from one generation to the next, bestowing value and life on it.

- These songs are of unknown author and composer, have no written resource and they depend on oral performance for popularity.

- They are characterized by verbal repetition, structural and musical symmetry, simplicity of the vocabulary, and stability of the rhythmic structure, therefore, they are easy to recite, memorize and repeat.

- These songs are generally the embodiment of the pilgrimage culture of the Copts, therefore, after the papal ban that prohibited the pilgrimage to Jerusalem, the Copts skillfully adapted these songs to be sung during visiting of the holy shrines of saints and martyrs inside Egypt, by replacing the name of the Christ, for example, with the name of the meant martyr or the verse contains Church of Sepulcher in Jerusalem with churches of saints:

For example, the song that is recited during " mulid " of Anpa Shenouda in Sohag in Upper Egypt, the verse of Church of Sepulcher, in previous song, is replaced with the Church of the Martyr to adequate the recent place (معوض, 2018):

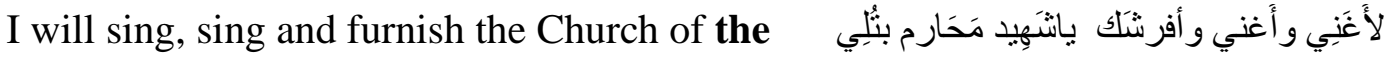

Martyr with decorated handkerchiefs

Another example, in the "mulid" of the Virgin Mary in Asyut in Upper Egypt, the verse of Church of Sepulcher, in previous song, is replaced with Church of the Virgin:

Church of the Virgin has stone threshold Stone threshold

$$
\text { عَتَبها حِجَارة كنيستَكَ ياعَدرا }
$$

To sum up, Hajj or pilgrimage rite is an integral part of the Egyptian identity, whether Copts or Muslims, both communities have the same pilgrimage culture, using songs to reflect their religious beliefs. This valued Coptic oral heritage need to be protected and revitalized; as P. Jeffery states that "critical evaluation on the non-musical evidence remains essential, for it can tell us much that purely musical evidence cannot" (Jeffery, 1992).

\section{Uncategorized References}

Alorshleme, M. P. y. (2012). Copts' Rituals and Traditions in the Church of Resurrection,

Jerusalem. Paper presented at the The Tenth International Congress of Coptic Studies in Rome Rome, Italy.

Armanios, F. Y. (2003). Coptic Christians in Ottoman Egypt: religious worldview and communal beliefs. The Ohio State University.

Aubrey, S. (1896). The letter of Paula and Eustochium to Marcella, about the Holy Places (386 AD). Palestine Pigrims, 1.

Basilios, A. (1991a). Dayr al-Sultan. In A. S.Atiya (Ed.), Coptic Encyclopedia (Vol. 3, pp. 872875): New York: Macmillan Publishing Company.

Basilios, A. (1991b). Jerusalem, Coptic See. In A. S. Atiya (Ed.), The Coptic encyclopedia (Vol. 4, pp. 1075-1089): Macmillan. 
Bernard, J. H. (1891). The Pilgrimatge of S. Silvia of Aquitania to the Holy Places:(circa 385 AD), Trans. by John H. Bernard: Palestine Pilgrims' Text Society.

Bowman, G. (1992). Pilgrim Narratives of Jerusalem and the Holy Land, A Study in Ideological Distortion'in Sacred Journeys, The Anthropoloqv of Pilqrimaqe, edited by A. Morinis: Westport, Connecticut, Greenwood Press.

Butcher, E. L. (1897). The Story of the Church of Egypt: being an outline of the history of the Egyptians under their successive masters from the Roman conquest until now (Vol. 2): Smith, Elder, \& Company.

Carswell, J. W. (1958). Coptic tattoo designs... With a foreword by Margaret Murray.(revised and expanded.): Faculty of Arts and Sciences, the American University of Beirut.

Ciggaar, K. N., Davids, A., \& Teule, H. G. (2003). East and West in the Crusader States: Context, Contacts, Confrontations: Acta of the Congress Held at Hernen Castle in September 2000 (Vol. 3): Peeters Publishers.

Danielson, V. (2000). The Coptic Orthodox Liturgy of St. Basil: With Complete Musical Transcription. Notes, 57(2), 481-482.

Dictionary, T. O. E. (Ed.) (1971) The Oxford English Dictionary. Oxford, United Kingdom: Oxford University Press.

Frenkel, Y. (1996). Muslim Pilgrimage to Jerusalem in the Mamluk Period. Pilgrims and Travelers to the Holy Land, 63-88.

Gregorios, B. (1991). Flight into Egypt. In A. S. Atiya (Ed.), The Coptic Encyclopedia (Vol. 4, pp. 863-866): Macmillan.

Jeffery, P. (1992). The lost chant tradition of early Christian Jerusalem: some possible melodic survivals in the Byzantine and Latin chant repertories. Early Music History, 11, 151190.

Meinardus, O. F. (1960). The Copts in Jerusalem.

Meinardus, O. F. (2003). Coptic saints and pilgrimages: American Univ. in Cairo Press.

Meinardus, O. F. A. (2002). Two thousand years of Coptic Christianity: American Univ in Cairo Press.

Runciman, S. (1951). A History of the Crusades: Volume 1, The First Crusade and the Foundation of the Kingdom of Jerusalem (Vol. 1): Cambridge: University Press.

Skeat, W. W. (1884). An etymological dictionary of the English language: Clarendon Press.

UNESCO. (2003). https://ich.unesco.org/en/what-is-intangible-heritage-00003.

UNESCO. (2005). https://en.unesco.org/news/new-inscriptions-lists-intangible-culturalheritage.

Viaud, G. (1991). Pilgrimages. In A. S. Atiya (Ed.), The Coptic Encyclopedia (Vol. 6, pp. 15831601): Macmillan.

Volokhine, Y. (1998). Les déplacements pieux en Egypte pharaonique: sites et pratiques cultuelles Pilgrimage and holy space in late antique Egypt (pp. 49-97): Brill.

Wamboldt, A. (2013). The Forbidden Pilgrimage.

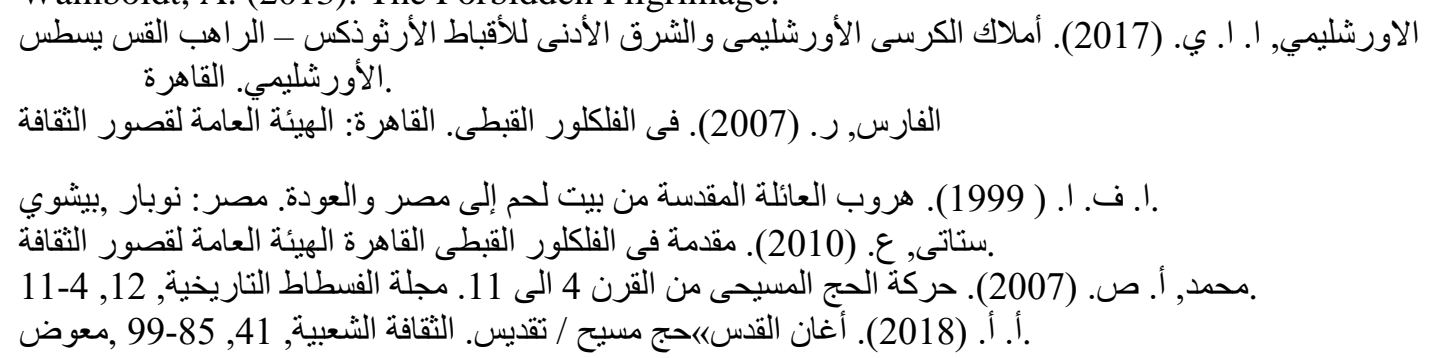


${ }^{1}$ Copts are the Christians of Egypt.

2 "mulid" or "mawlid" is an Arabic word means the festival held in honor of Coptic saints, Schielke S.,The Berils of Joy:Contesting Mulid Festival in Contemporary Egypt,2012,p.xi ${ }^{3}$ Jerusalem was at first the capital of all Israel, later of the Kingdom of Judah; the chief city of Palestine. The earliest historical mention of Jerusalem comes from the El-Amarna Tablets about fifteenth century B.C. where Pharaoh Amenhotep III had extended Egyptian rule so as to include Syria, Mesopotamia, Babylonia, and Assyria. Its name is written in the Old Testament and upon most of the old Hebrew coins "Yerushalayim", meaning "possession of peace", "foundation of peace" or "of Shalem [God of peace]"; according to the Midrash it is made up of "Shalem," the name given to the city by Shem, and "Yir'eh," that given to it by Abraham (Gen. R. 1vi. 10). In the Greek period the name was Hellenized into Iєрoбó $\nu \nu \mu \alpha$ while The Arabs preserved the ancient forms "Urishalam, "Uraslam", or more commonly "Bait al-Makdis" or "alMukaddas" and in modern parlance, "Al-Kuds al-Sharif" or simply "Al-Kuds" meaning "the Sanctuary.", Gottheil R., Meyer M.A., "Jerusalem", Jewish Encyclopedia, V.7, 1906, pp.118-119, http://www.jewishencyclopedia.com/articles/8604-jerusalem.

${ }^{4}$ The Infant Jesus, the Blessed Virgin Mary, and Saint Joseph, accompanied by Salome, mother of Zebedee's children, made the journey to Egypt in compliance with a divine message communicated to Joseph in a dream, directing them to leave Bethlehem and seek refuge in Egypt to escape the wrath of Herod the Great (Mt. 2:13), (Gregorios, 1991).

${ }^{5}$ The Five Pillars are the core beliefs and practices of Islam:- Profession of Faith (shahada), Prayer (salat), Alms (zakat), Fasting (sawm) and Pilgrimage (hajj) to Mecca, http://www.oxfordislamicstudies.com/article/opr/t125/e1859

${ }^{6}$ When Jesus Christ was condemned to death during the reign of the Roman governor (Pilate), the Roman soldiers took him to be crucified in a place outside the city called Golgotha, الراهب (اله القس يسطس الأورشليمى، أملاك الكرسي الأورشليمي، ص 69.

${ }^{7}$ Mary the Penitent or Mary of Egypt was born in Alexandria, where she lived and worked as a prostitute. One day she decided to make pilgrimage to Jerusalem to "expand her business". However, at the entrance to the Holy Sepulcher, she was denied access to see the True Cross by an icon of the Virgin Mary. After being mystically prevented from entering the building multiple times, Mary beseeches the Virgin to allow her to see the Cross in exchange for her devotion to the Christ and commitment to a life of asceticism. At this, she is allowed entrance and witnesses the glory of the Cross, after which she forsakes her old life to live in the desert as an ascetic and clairvoyant, http://www.monachos.net/content/patristics/patristictexts/182-lifeof-mary

${ }^{8}$ The researcher depended on different Arabic resources of Coptic folklore to get the songs including:

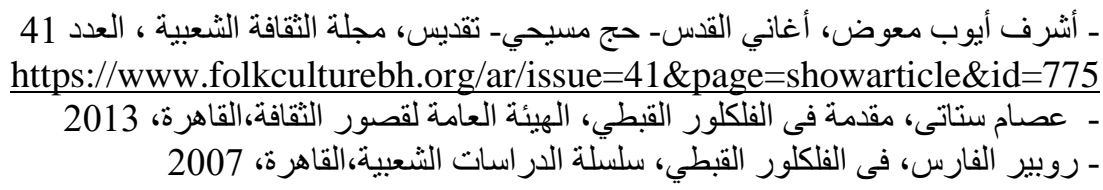

${ }^{9}$ Jacob's Well is a holy well associated with Prophet Jacob, located in Jerusalem near Tell Balata and also called Samria Well as it the place where the Christ and the Woman of Samaria met while he was resting after a long journey (John 4:7-15), Binz S.J., Jerusalem, The Holy City, Twenty-Third Publications, UAS, 1989,P.116. 
${ }^{10}$ Canaan Land refers to the region of the southern Levant including Jerusalem which has many events that are associated with the Christ and his life, French B., Glimpses of Canaan Land, USA, 2009, P.5.

${ }^{11}$ Palm Sunday, also known as "Hosanna Sunday", is the seventh Sunday in the Great Lent whe re the Christians commemorate the Christ's triumphal entry into Jerusalem. Hosanna" is a Hebre w term signifying "Save us, we beseech Thee" which occurs in Psalm 118:25. During the feast o $f$ the Tabernacles, it formed a part of the refrain sung by the people of Jerusalem while waiving palms and olive branches. When Christ entered Jerusalem, people welcomed Him by using palm and olive branches, hence this Sunday is called Palm Sunday. The Coptic Orthodox Church cele brates Palm Sunday with a special rite including offering of incense, processional hymn, doxolo gies and the Divine Liturgy,

Basilios, Archbishop, “Hosanna”, in Coptic Encyclopedia, 1991, V.4, p.1258, edited by Atiya, Aziz Suryal.

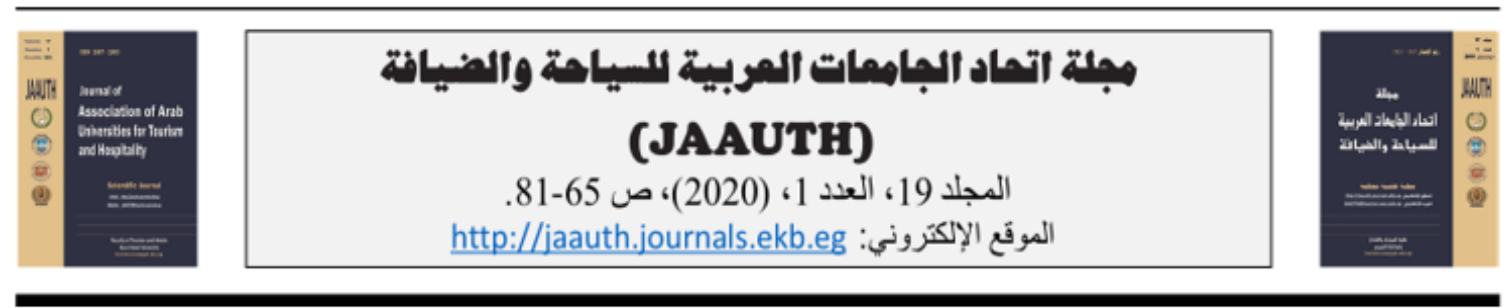

$$
\begin{aligned}
& \text { الأغانى الروحية للحج المسيحى الى القدس: ملمح غير مادى لطقس قبطى } \\
& \text { منال محمود عبد الحميذ } \\
& \text { قسم الإرشاد السياحى، كلية السياحة والفنادق، جامعة الإنكندرية. }
\end{aligned}
$$

\begin{tabular}{|c|c|}
\hline & \\
\hline 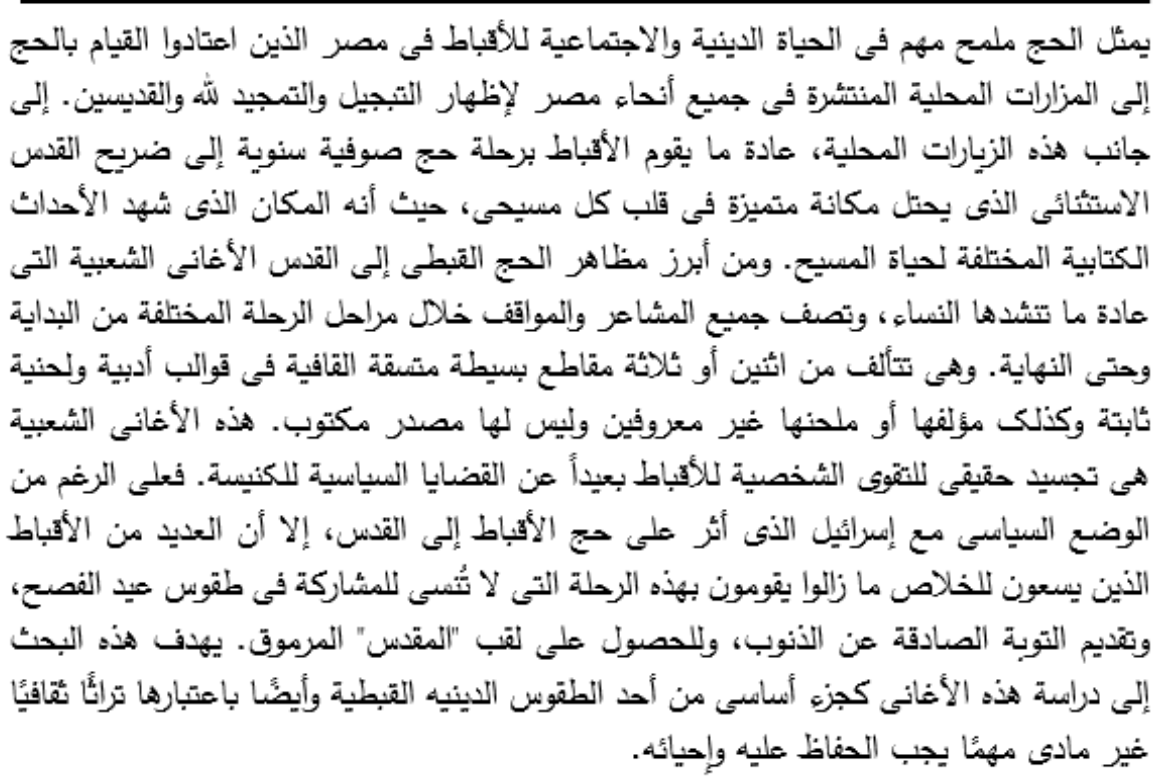 & 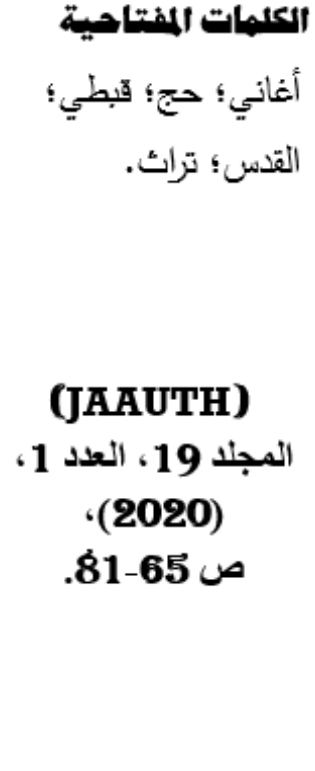 \\
\hline
\end{tabular}

